\title{
DEMOCRACIA E COMPROMISSOS: REFLEXÕES SOBRE O CONSTITUCIONALISMO E DESACORDOS
}

\section{Bruno Meneses Lorenzetto ${ }^{1}$}

\section{Resumo}

O artigo trata da questão sobre os compromissos e suas relações com as formas democráticas de organização social. Teve como objetivo analisar diferentes perspectivas a respeito da tensão entre o constitucionalismo e a democracia, em especial as críticas às noções de pré-compromisso, perante a qual procura apresentar uma alternativa para a dicotomia, que seria a da tensão colocada em uma dimensão temporal estendida. A metodologia empregada para a confecção do artigo pautou-se na investigação de documentos doutrinários, de precedentes e de normas. Tais elementos serviram de suporte para as considerações formuladas sobre o tema investigado. Na conclusão apresentou-se a proposta de compreender os compromissos como razões para a ação política.

Palavras-chave: Autogoverno; Compromissos; Desacordo; Democracia; Constitucionalismo.

\section{INTRODUÇÃO}

O artigo está dividido em três tópicos. No primeiro são apresentadas as ideias de Elster e Holmes sobre a formação de compromissos e seus reflexos na organização política das sociedades. No segundo tópico, são desenvolvidas as críticas de Waldron à noção de compromisso e agrilhoamento. Na última parte, são discutidas as propostas de Rubenfeld para compreensão da tensão entre constitucionalismo e da democracia em uma extensão temporal contínua, alternativa que responde à dicotomia estabelecida entre os autores dos dois primeiros tópicos e apresenta uma perspectiva inovadora para refletir sobre os compromissos e os desacordos e, por extensão, o constitucionalismo e a democracia.

\section{A FORMAÇÃO DE COMPROMISSOS E O AGRILHOAMENTO}

Elster explica, na primeira versão de sua teoria, que um ator paramétrico trata seu ambiente como uma constante, enquanto um ator racional estratégico entende que o seu ambiente é constituído por outros atores, e

\footnotetext{
${ }^{1}$ Professor de Direito da Pontifícia Universidade Católica do Paraná. Visitng Scholar na Columbia Law School, Columbia University, New York (2013-2014). Doutor em Direito pela UFPR na área de Direitos Humanos e Democracia (2010-2014). Email:bruno_lorenzetto@yahoo.com.br 
que ele é parte deste ambiente, e que os outros sabem disso. ${ }^{2}$ Logo, uma condição necessária, ainda que insuficiente, para a racionalidade coletiva é a transição para o pensamento estratégico (ELSTER, 1993.p. 18).

$\mathrm{Na}$ interação que ocorre no modo estratégico ou da teoria dos jogos, cada ator deve compreender as intenções dos outros atores, inclusive, levar em consideração que as intenções deles são baseadas em suas expectativas a respeito dos propósitos alheios. ${ }^{3}$

Elster utiliza, por isso, uma metáfora para sua teoria da racionalidade imperfeita ${ }^{4}$ dos atores sociais, a figura de Ulisses acorrentado ao mastro de seu barco, e assume que este não era completamente racional, mas possuía em seu favor a consciência de que era fraco, falível. Logo, o autor, em sua obra “Ulisses e as sereias", expõe que: “(...) as sociedades, assim como os indivíduos, entenderam que era útil se acorrentar (...)” (ELSTER, 1993. p. 37) como no caso da promulgação de constituições.

De acordo com Gargarella, a transferência desta metáfora ao plano constitucional parece óbvia: “(...) do mesmo modo em que Ulisses pode ganhar liberdade, ao invés de perdê-la, ao se incapacitar para certas ações, uma sociedade também pode expandir suas capacidades ao se auto-impor determinados limites" (GARGARELLA, 2008. (b) p. 30).

O papel da Constituição seria, de acordo com esta perspectiva, o de impor limites capacitadores sobre os poderes de autogoverno da sociedade. Ao reconhecer que esta ação suporta riscos, como a opressão de grupos minoritários, a censura de partidos opositores, a ação racional de uma sociedade precisaria demarcar certos limites irrenunciáveis, com a capacidade de aprimorar a liberdade das gerações futuras.

De imediato, surgem questões que tratam de problemas da prática do "acorrentamento" (binding oneself) em outros ramos como: "quem acorrenta quem?" e "quem tem o direito de acorrentar quem?". Elster dá o exemplo de que, para parar de fumar, as pessoas usam meios que acrescentam força a esta resolução interna, com vistas a manter este pré-compromisso. Desse modo, a autopunição surge como uma das técnicas de autocontrole (ELSTER, 1993.p. 39).

O relevante é que a decisão de se atar a determinada conduta ocorre em um tempo inicial específico e medidas devem ser tomadas para que seja possível manter a decisão anterior no futuro. Por isso, segundo Elster, o processo de se acorrentar parece demandar que a vontade das pessoas seja depositada em uma estrutura externa por alguma medida de tempo (ELSTER, 1993.p. 43).

\footnotetext{
${ }^{2}$ De acordo com Elster, a teoria da escolha racional é, antes de tudo, normativa, apenas em um segundo nível ela é explanatória, descritiva. Ela primeiro procura definir como os agentes deveriam agir para conquistar seus objetivos. A partir disso, procura explicar as ações sob a hipótese de que eles efetivamente se comportem de tal maneira. (ELSTER, 2009.p. 14).

${ }^{3}$ Sobre diversas concepções acerca da teoria dos jogos, ver: BARRY, 2001.

${ }^{4}$ Primeiro, há uma limitação ligada à consistência, uma vez que o agente adotou um princípio normativo ou uma teoria causal ele não pode abandoná-la, mesmo que esta não permita ele satisfazer seus desejos. Depois, há uma limitação da imperfeição, que está conectada com o fato de que a coincidência entre a motivação manifestada e o desejo não deve ser muito evidente. (ELSTER, 20009.p. 58-59).
} 
Figurativamente, faz-se possível imaginar o mastro do navio ou a Constituição de um país como a estrutura externa que agrilhoa vontades por um tempo determinado. Essa característica seria, para Elster, intrínseca ao ser humano, apenas o homem possui a capacidade de superar suas fraquezas pelo uso de técnicas como o pré-compromisso.

Contudo, o pré-compromisso não é tão simples quando se procura transpor o planejamento (racionalestratégico) para o campo político, pois se, por um lado, os indivíduos são livres para se agrilhoar por meio de leis, como cintos de segurança, contra seus arroubos impulsivos, por outro lado, sérios problemas surgem quando tais restrições são impostas aos indivíduos, contra sua vontade anterior (ELSTER, 1993.p. 84).

As consequências dessa imposição podem ser observadas na questão da necessidade ou não de um Estado paternalista, que vincula os indivíduos a determinadas condutas que entende como adequadas ao corpo político-social, sem consultá-los, ou com a previsão de sanções ante o descumprimento delas.

O temor que se atrela a isso é o da restrição de direitos e liberdades, supostamente em favor do bemcomum ou de futuros benefícios que nem sempre as pessoas desejam. Porém, é possível observar que a retórica de países com tradição autoritária seja constante nesse sentido, acrescido de fatores messiânicos e acabe apenas por acentuar as desigualdades e a ausência de democracia e liberdade nesses locais.

Desse modo, descortina-se outro viés presente na embarcação de Ulisses, a política, eis que, uma democracia, segundo Elster, pode rumar por águas incertas, com a constante reavaliação de planos do passado, de modo a se aproximar da inconsistência e a ineficiência (ELSTER, 1993. p. 88).

Com a preocupação de manter a democracia nos limites exigidos para sua eficiência e estabilidade, foram criadas, nas democracias modernas, instituições, as quais podem ser interpretadas como dispositivos de précompromisso. Assim, por meio das instituições é possível identificar, com níveis de precisão distintos, quando os políticos (originários) decidiram que certos valores eram muito importantes, ou certos instrumentos muito perigosos, para serem sujeitados ao controle dos políticos (futuros) (ELSTER, 1993.p. 90).

O exemplo de instituição que se amolda à descrição de Elster são as Constituições modernas, que incorporaram princípios que constituem o núcleo duro dos Estados democráticos de Direito, em um movimento que teve início após a Segunda Guerra Mundial, mas que já possuía exemplos (e os incorporou) nas Constituições e Declarações de Direitos do século XVIII, frutos da revolução americana e francesa (ARENDT, 1963).

As incertezas a respeito do futuro podem partir de duas fontes, uma lei pode ensejar ambiguidade ou se encontrar em constante mutação. Uma perspectiva estabilizadora pode demandar, portanto, que as leis mantenham constância e não sejam ambíguas, pois, se é possível antever as decisões de uma Corte, é possível que medidas de precaução sejam adotadas antecipadamente. 
Por isso, a assembleia constituinte passa a ter um papel fundamental. No entendimento de Elster, ela dispõe as normas fundamentais que deverão ser seguidas por todas as gerações futuras e, além disso: "Apenas a assembleia constituinte realmente é um ator político, no sentido forte da la politique politisante; todas as futuras gerações estão restringidas a la politique politisée, ou a atuação do dia-a-dia com as normas fundamentais." (ELSTER, 1993.p.93).

Assim, um Estado pode se agrilhoar por meio de uma Assembleia Constituinte, ao garantir poderes de decisão ao Judiciário, e demandar um quórum elevado para a promoção de mudanças de normas fundamentais. Mas, disso surge, de maneira inevitável, um paradoxo, qual seja, cada geração almeja possuir a liberdade para atar seus sucessores, enquanto ocupa a posição de liberdade ante seus predecessores.

Em termos análogos, na "Teoria da Justiça” de John Rawls, o recurso expositivo central é o da posição original..$^{5}$ Por isso, a constituição da posição original reflete nas ideias básicas acerca do que é relevante para a justiça e do que não o é. Estas ideias dão sustento à construção em forma de estipulações sobre o que se deve dizer às pessoas que realizam escolhas e que informação não deveria ser comunicada.

Para assegurar uma escolha imparcial, na posição original, deve-se negar às pessoas todo o conhecimento de seus atributos pessoais. Contudo, elas possuem certa informação geral sobre as características dos seres humanos e das sociedades humanas. Assim, a partir da necessidade de usar esta informação para delinear os princípios de justiça, decorre que os princípios serão válidos apenas se os dados sobre os quais baseiam sua decisão são corretos. ${ }^{6}$

Tanto as relações entre os países, como as relações entre as gerações propõem sérios desafios ao projeto de Rawls, no sentido de reconciliar a vantagem mútua e a imparcialidade com bases na justiça. As condições incluem um "véu de ignorância", que impede aos membros da sociedade, ou a seus representantes, ter acesso a diversos tipos de informações que poderiam inclinar sua decisão acerca de quais princípios defenderiam. Assim, os membros da sociedade não sabem quais são suas vantagens naturais ou sociais. ${ }^{7}$

\footnotetext{
${ }^{5}$ Segundo Rawls: "Afirmei que a posição original é o status quo inicial apropriado para assegurar que os consensos básicos nele estabelecidos sejam eqüitativos. Esse fato delimita o conceito de 'justiça como eqüidade’. Está claro, portanto, que eu quero afirmar que uma concepção de justiça é mais razoável que outra, ou mais justificável no que diz respeito à justiça como eqüidade', quando as pessoas racionais na situação inicial escolhem os seus princípios para o papel da justiça preferindo-os aos de outra concepção." (RAWLS, 2000.p. 19.).

${ }^{6}$ Traduzindo isto fora da linguagem da posição original, pode-se propor o ponto ao se afirmar que os princípios de justiça de Rawls se dão sob as condições que Rawls especifica. Por isso, as pessoas que estão na posição original são construções da teoria. Diferem das partes, que são pessoas na vida real, com informação completa sobre elas mesmas e sua sociedade.

${ }^{7}$ Segundo Gargarella: "Os sujeitos que Rawls imagina surgem afetados por uma circunstância particular. Ocorre que estão sob um 'véu de ignorância', que os impede de conhecer qual é sua classe ou seu status social, a sorte ou desventura que tiveram na distribuição de capacidades naturais, sua inteligência, sua força, sua raça, a geração à qual pertencem etc. Tampouco conhecem suas concepções do bem ou suas propensões psicológicas específicas. Por outro lado, esse 'véu' não os impede de reconhecer certas proposições gerais, tais como as descobertas básicas que as ciências sociais fizeram em matéria de economia, psicologia social etc." (GARGARELLA, 2008.p. 21).
} 
Sob tais condições, as partes deveriam, de acordo com Rawls, concordar com dois princípios de justiça. O primeiro proporcionaria, a cada um na sociedade, direitos civis e políticos iguais: ninguém teria nenhuma razão para se contentar com menos. O segundo especificaria uma competência aberta por posições ocupacionais vantajosas e que as desigualdades econômicas devem ser dispostas de modo tal que não haja outra maneira de conseguir que o estrato menos vantajoso na sociedade possa, em sua totalidade, estar melhor (RAWLS, 2000).

Rawls questiona se as pessoas na posição original, que são contemporâneas e sabem que o são, têm obrigações e deveres quanto a terceiras partes, como é o caso, por exemplo, de seus descendentes imediatos. Contudo, o autor rechaça essa posição, pois o objetivo da justiça como equidade seria derivar todos os deveres e as obrigações de outras condições. ${ }^{8}$

Dado que, na posição original, as pessoas não sabem quem são elas mesmas (e também quem serão seus descendentes), o mecanismo do véu de ignorância transmuta esse interesse limitado em um interesse pelas gerações posteriores em seu conjunto. Mas, de onde surge esta suposição original?

Uma reposta possível é que ela é inteiramente ad hoc. A especificação dos motivos das pessoas na posição original deve ser intrinsecamente razoável. A força motivadora deve estar proporcionada pelo seu conhecimento de que, quando deixam de estar atrás de um véu de ignorância, descobrirão que efetivamente se preocupam com o bem-estar de seus descendentes. ${ }^{9}$

Isso, contudo, expõe as limitações de qualquer tentativa de enquadrar a justiça intergeracional com a doutrina das circunstâncias da justiça, pois faz com que as obrigações da geração presente ante as gerações futuras dependam exclusivamente da boa vontade afetiva dos contemporâneos para com seus descendentes. Rawls entende que os interesses das gerações mais remotas serão tomados na medida em que haja "laços sentimentais" entre as gerações sucessivas. E prossegue com esse argumento, ao invocar essa cadeia de interesses pelas gerações seguintes. ${ }^{10}$

As diretrizes da teoria de Rawls indicam que as pessoas deveriam formular princípios para governar as relações intergeracionais e atender à possibilidade de que poderiam, elas próprias, aparecer em qualquer momento

\footnotetext{
${ }^{8}$ Rawls explana que: "Parece razoável supor que as partes na posição original são iguais. Isto é, todas têm os mesmos direitos no processo da escolha dos princípios; cada uma pode fazer propostas, apresentar razões para sua aceitação e assim por diante." (RAWLS, 2000. p. 21). Ainda, de acordo com Rainer Forst: "Tal como Larmore e Ackerman, Rawls contesta que o liberalismo estaria fundamentado numa determinada concepção de bem. Mas diferente de Ackerman, fornece razões morais universais para seu argumento e, diferente de Larmore, está disposto a reconhecer certos valores substantivos, que pertencem ao conteúdo moral da teoria da justiça como equidade." (FORST, 2010.p. 74)

${ }^{9}$ Nos termos de Gargarella: "Conforme uma leitura possível de dita tradição, tratar a cada indivíduo como igual leva a uma preocupação para assegurar que a vida de cada indivíduo dependa das escolhas que cada indivíduo realiza, e não das meras circunstâncias nas quais ele nasce." (GARGARELLA, 2008 (b).p. 33). Cf. ALEGRE, 2007.

${ }^{10}$ Se adotarmos uma perspectiva menos benigna, e nos centrarmos não tanto na proporção justa da acumulação do capital como na proporção justa da poluição do ar ou das águas, da degradação da paisagem, da diminuição dos recursos naturais, da destruição das espécies, da criação de riscos de radiação ou da iniciação de modificações potencialmente desastrosas para o clima mundial, observa-se que não já não se dá a mesma relação conveniente. Cf. BARRY, 2001.p. 210.
} 
histórico - aplica-se a mesma lógica das diferentes posições sociais para a questão geracional. Assim, se as pessoas propõem demandas muito rigorosas às gerações anteriores, para que elas se sacrifiquem para beneficiar seus sucessores, todos lamentarão pertencer às primeiras gerações. De outra sorte, se as pessoas das gerações anteriores forem pouco comprometidas com os cenários futuros, não será desejável pertencer às gerações posteriores.

As pessoas na posição original devem escolher um princípio com o qual possam viver, qualquer que seja o lugar que ocupam na sequência, sob a condição de que todas as demais tenham feito sua parte de acordo com as mesmas regras. Por isso, as pessoas na posição original deveriam buscar estabelecer um programa de economia justo e estimar quanto desejariam economizar em cada estágio a favor de seus descendentes imediatos, ante o que eles se sentiriam autorizados a reclamar de seus predecessores imediatos. ${ }^{11}$

Para Elster, a estratégia de Ulisses é a de acorrentar as gerações futuras ao se estabelecer uma Constituição que inclua cláusulas que dificultem sua fácil alteração. Logo, a assembleia constituinte possui um caráter único e privilegiado, que não é fundado em qualquer direito, mas por causa de um "acidente histórico" (ELSTER, 1993.p. 94).

Em casos raros, os constituintes deixam questões fundamentais do corpo constitucional em aberto para decisões das futuras gerações. Contudo, não deixa de ser interessante que teóricos políticos levaram a sério a questão de assembleias constituintes periódicas, de maneira que todas as pessoas, ao menos uma vez na vida, tivessem a oportunidade de decidir sobre os direitos fundamentais que regeriam a sociedade em que vivem, ao invés de depender da herança política de gerações passadas (JEFFERSON, 1973).

Elster deu continuidade a sua teoria do pré-compromisso e aprofundou o debate, após as críticas sofridas pela sua obra inicial. Em sua obra "Ulisses liberto" (ELSTER, 2000), em que debate a relação entre Constituições e suas possíveis "amarras", reitera que Constituições políticas podem ser usadas como dispositivos de précompromisso ou autorrestrição, criadas pelo corpo político com a finalidade de se proteger contra sua própria tendência de tomar decisões equívocas. Mas expõe a ressalva que alguns dispositivos que estão disponíveis para o agrilhoamento dos indivíduos, não podem ser usados para a coletividade, assim como algumas razões que motivam os indivíduos a realizarem pré-compromissos, podem não possuir qualquer sentido análogo no caso da Constituição (ELSTER, 2000.p. 90).

\footnotetext{
${ }^{11}$ Para Dworkin: "A teoria contratualista de John Rawls é muito mais complexa. Em sua mais recente versão, elaboram-se condiçōes para a escolha de modo que expresse, primeiro, uma concepção de pessoas como cidadãs de uma comunidade livre e igual, cada uma das quais tendo o interesse 'moral' da mais alta ordem de proteger sua capacidade de justiça e sua capacidade de racionalmente criar e revisar concepções do bem e, em segundo lugar, princípios de razoabilidade adequados à cultura política das democracias liberais ocidentais. Assim, membros da 'posição original', na qual são escolhidos os princípios de justiça, fazem as vezes de fiduciários de outras pessoas, cuja posição social e econômica, talentos e habilidades, gostos e concepções do bem ficam ocultos para o fiduciário sob o 'véu da ignorância'. A estratégia de Rawls para reconciliar a liberdade e a igualdade parece um misto das estratégias constitutiva e dos interesses." (DWORKIN, 2005, p. 181).
} 
O constitucionalismo pode ser visto a partir de uma perspectiva estritamente negativa, como um instrumento institucional que possui como função a retirada de certas decisões do processo democrático, ou seja, "amarrar as mãos" da comunidade. Como poderia ser justificado um sistema que obstrui a vontade da maioria? Tal visão do constitucionalismo desarticulado da democracia não é apenas indesejável, ela tende a ser perigosa. A Constituição, observa Holmes, não passaria de um dispositivo para limitar o poder do governo (HOLMES, 1995. p. 135).

Parte-se da premissa de que os cidadãos do presente são míopes e movidos apenas por impulsos, são descontrolados. A Constituição seria, portanto, o remédio para esses momentos impulsivos, ela é o "Pedro sóbrio" enquanto o eleitorado é o "Pedro bêbado". Ao se atar ao mastro os cidadãos poderiam atingir objetivos sólidos e de longo período (HOLMES, 1995. p. 135). Uma das questões que a metáfora esquece é que os vivos, que possuem a soberania popular, que precisam dar vida para a Constituição sempre podem fazer a pergunta se eles querem que a Constituição continue sendo relevante para a comunidade política. A pura posição negativa do constitucionalismo aliena a possibilidade da comunidade se autodeterminar. ${ }^{12}$

A perspectiva que eleva o autogoverno à condição independente de pré-condições também se apresenta como arriscada. Se há acerto da parte dos teóricos que questionam a possibilidade de uma geração agrilhoar as gerações futuras, a ausência de um direito e uma moral podem transformar o futuro em um campo deserto. Por isso, tal imagem também é parcial, incompleta.

Para Holmes, a ideia de unidade precisa ser conjugada em termos intergeracionais, se a geração presente é vinculada pelas decisões de seus ancestrais isso pode ocorrer pelo fato de que os mortos e os vivos constituem um povo. Mas tal concepção de diferentes gerações em um mesmo corpo é tão problemática quanto demandar que uma pessoa adulta mantenha as promessas feitas em sua juventude (HOLMES, 1995. p. 145).

A ideia de um governo conduzido apenas pelos vivos é contraproducente, pois as decisões presentes logo pertencerão ao passado, ainda que orientadas para a construção de estruturas que durem em um momento posterior. Ainda que se possa tratar o momento constituinte como um instante privilegiado para a produção das normas que irão definir as principais estruturas da comunidade política, os fundadores não podem ser erigidos à condição de "anjos onipotentes" (HOLMES, 1995. p. 160) que interferem no contínuo da história a partir de uma perspectiva exterior.

Os fundadores não são os criadores de um milagre, ainda que seus projetos estejam disponíveis para adorações diacrônicas. Os constituídos, de outra sorte, não podem ser observados como condenados à repetição,

\footnotetext{
12 "For a surprisingly large number of serious thinkers, then, constitutional democracy remains a paradox, if not a contradiction in terms. Yet all working democracies, as nearly everyone admits, operate within boundaries set by stabilizing constraints." (HOLMES, 1995. p. 137).
} 
à reprodução dos mesmos fenômenos que os fundadores, eis que o próprio gesto da busca do mesmo se realiza em um outro momento, outro contexto.

Holmes propõe a inversão dos vetores das duas tradições concorrentes entre constitucionalismo e democracia. A nova máxima que poderia ser derivada seria que a liberdade é uma prisão e a prisão é uma liberdade. Aqueles que defendem formas puras de autogoverno não percebem a economia que o passado promove, os embates dos mortos não precisam mais ser invocados a todo momento, o agrilhoamento fornecido pelo passado pode ser libertador para novas relações intersubjetivas. Uma visão elastecida do funcionamento das Constituições permite ver que as restrições constitucionais são habilitadoras, as regras podem ser criativas. ${ }^{13}$

Logo, pode-se transpor o conceito negativo de constitucionalismo para um positivo, afirma Holmes, se for considerado que os limites fortalecem e que a autolimitação é uma forma de habilitar outras atividades. Porém, a metáfora de Ulisses continua inapropriada, pois os fundadores procuram não apenas limitar o poder, mas criar e organizar os poderes e fornecer valores e direções para sua condução. Um governo limitado auxilia na criação do self, na produção de unidade para a comunidade política, e a autoincapacitação do sujeito é um símbolo inadequado para tratar da fundação da nação (HOLMES, 1995. p. 174).

A metáfora de Ulisses para o processo de criação de Constituições é apenas válida de maneira parcial. Além disso, a ideia de uma sociedade se agrilhoando é, no mínimo, controversa, pois, se, de um lado, as Constituições podem atar outras pessoas, como o caso de gerações futuras, ao invés de serem atos de constrição própria; por outro lado, elas podem não deter o poder para conseguir atar qualquer coisa.

A estrutura das Constituições prevê que a Constituição deve ocupar um lugar superior em comparação com a legislação ordinária. Por isso, costumeiramente, são moldadas para dificultar a mudança de seus respectivos textos, com a adoção, por exemplo, de quóruns qualificados. Porém, a produção de emendas não é impossível. Embora alguns temas das constituições possam se encontrar em uma disposição especial na organização sistêmica desta, como a impossibilidade de mudança do texto de artigos fundamentais ou da estrutura da própria Constituição, Elster lembra que a ação extraconstitucional sempre continua possível (ELSTER, 2000. p. 94). A partir disso, entende-se que mesmo este "núcleo duro" seria passível de mudanças.

No desenvolvimento de sua teoria do pré-compromisso, o autor expõe que tentativas de atar a sociedade de maneira muito estreita podem ser problemáticas, pois teriam o potencial de produzir efeitos contrários (ELSTER, 2000. p. 95), ou seja, os cidadãos podem reagir à própria ideia de serem acorrentados a determinadas instâncias de poder, podendo se rebelar contra esta.

\footnotetext{
13 "As I explained in the last chapter, constitutions may be usefully compared to the rules of a game and even to the rules of grammar. While regulative rule (for instance, 'no smoking') govern preexistent activites, constitutive rules (for instance, 'bishops move diagonally') make a practice possible for the first time." (HOLMES, 1995. p. 163).
} 
Pode ser lembrado que no repertório das motivações usadas pelas colônias para demandar libertação, tendia a surgir nos discursos: a opressão, a falta de legitimidade, a ausência de identificação e a necessidade de autonomia, ou seja, de produção das próprias regras, independentemente de um poder “exterior”.

Apesar dos problemas decorrentes de amarras muito apertadas, o papel do constitucionalismo seria de importância significativa, eis que caberia a ele assegurar uma mudança cadenciada da Constituição. Além disso, incumbiria à Constituição a regulação da vida política, como a criação do próprio ordenamento jurídico em que irá se assentar.

Assim, desde uma perspectiva liberal, competiria à carta de direitos a proteção dos cidadãos da interferência indevida do governo, bem como regular a máquina de governo, mediante o estabelecimento do modo de eleição e representação, as funções do governo, a separação de poderes, freios e contrapesos, dentre outros (ELSTER, 2000.p. 100).

Outro problema enfrentado por Elster diz respeito ao fato de que, se as constituições partem de uma assembleia constituinte, deveria esta ser submetida a limitações e a pré-compromissos? O debate neste ponto parece se aproximar ao problema da necessidade de um fundamento último para a legitimação de corpos legislativos, pois as assembleias constituintes não poderiam, em tese, criar-se espontaneamente, puxar os cadarços da própria bota para sair do pântano. ${ }^{14}$

Porém, Elster joga luz sobre a questão para mostrar que, no início do debate sobre as constituições modernas, enquanto uma corrente entendia que era autoevidente o fato de a assembleia não possuir poderes para destruir ou limitar seu criador, como, por exemplo, o rei, para outros, contudo, era também evidente que a assembleia poderia fazer aquilo que bem desejasse, pois era a incorporação da vontade da nação (ELSTER, 2000. p. 109).

A questão do "paradoxo da democracia" surge de maneira exponencial. Enfrenta-se, em um polo, a assembleia que, na medida do possível, procura se libertar do passado, de todos pré-compromissos que a precederam. No outro polo, almeja o poder de criação normativa que se estenda sobre as gerações futuras, com a garantia de que elas estarão agrilhoadas de tal modo que não será fácil libertar-se da herança legada por eles.

Em consonância com o "paradoxo da democracia", em que uma geração procura se libertar, mas acorrentar as futuras, Elster trata do paradoxo da onipotência. Se a relação com os "pais fundadores" é, no mínimo, turbulenta, a relação dos poderes no caso da onipotência de um deles pode ser dramática. Por isso, defende o autor que o poder, para ser efetivo, deve ser dividido; e a onipotência, longe de ser uma benção, pode ser uma maldição (ELSTER, 2000. p. 146).

\footnotetext{
14 "The issue, briefly described, is one of 'constitutional bootstrapping,' the process by which a constituent assembly severs its ties with the authorities that have called into being and arrogates some or all of their powers to itself." (ELSTER, 1994. p. 57).
} vol.08, nº. 03, Rio de Janeiro, 2015.pp. 1602-1628 
O conceito analisado aproxima-se da definição da tirania, segundo a qual se um poder detém os meios de produzir qualquer lei ou fazer qualquer coisa a qualquer tempo, ele não poderá limitar seu próprio poder de ação ou de legislação. ${ }^{15} \mathrm{~A}$ discussão, que teve seu início no plano teológico, sobre a onipotência divina, foi transplantada para o campo da soberania política, e entende-se que é uma descrição das características que compõem uma tirania. Segundo Elster: "(...) a separação de poderes pode reduzir a corrupção e prevenir que um ramo do governo interfira nos objetivos dos outros"(ELSTER, 2000. p. 153). Um exemplo do uso preventivo da separação de poderes seria o da distribuição por sorteio dos casos aos magistrados, em que se evitaria, em alguma medida, a interferência política no Judiciário.

Assim como uma sociedade pode rejeitar amarras muito apertadas, um pré-compromisso constitucional também pode ser alvo de opositores. Os dois problemas potenciais que enfrenta, nesse âmbito, são o conflito entre pré-compromisso e eficiência e pré-compromisso e democracia.

O primeiro se situa ante a possibilidade de uma amarra constitucional, incompatível com a flexibilidade para a ação, que pode ser demandada durante uma crise. Portanto, o temor que se enfrenta é o de um "pacto de suicídio", pois, em tempos de crise, como no caso de uma guerra, deve haver uma previsão legislativa que conceda maior liberdade orçamentária ao governo do que em tempos de paz, sob pena de que a legislação promova um estrangulamento do próprio governo. O segundo problema emerge quando os agentes que exercem as funções de pré-compromisso não estão submetidos ao controle democrático. ${ }^{16}$

O golpe final que Elster desfere em sua teoria anterior é o seguinte: se em "Ulisses e as sereias" ele havia se aproximado da ideia de que as constituições poderiam ser observadas como dispositivos de pré-compromisso, e que as sociedades deveriam se acorrentar com elas, estas afirmações são eminentemente contestáveis, nos planos conceitual, causal e normativo (ELSTER, 2000.p. 167). ${ }^{17}$

\footnotetext{
${ }^{15}$ Elster observa o problema da legitimação ou da "autorização" no caso francês. Em Paris, os debates sobre a verificação se tornaram importantes para a auto-ransformação dos "Estados Gerais” na Assembleia Nacional. Dois casos foram apresentados. Primeiro, a nobreza demandava que cada ordem verificasse o poder seus próprios delegados enquanto o terceiro estado demandava uma verição conjunta, realizada pelas três ordens. O clero havia dito desde o início que seguiria o entendimento final entre as outras ordens. Segundo, como a nobreza percebeu que suas propostas não avançavam, aceitou que o Rei fosse o juiz dos casos em discussão, o que foi rejeitado pelo terceiro estado. Enfrentava-se um dilema: por um lado, o terceiro estado não aceitava o julgamento de um poder externo (Rei), por outro lado a autoverificação criava um círculo vicioso em que a Assembleia não poderia verificar as credenciais sem ser constituída. A resposta para tal questão foi realizada de maneira pragmática: o terceiro estado se autodeclarou constituído, pois afirmava que seria impossível acreditar que a maioria daqueles que se apresentavam como delegados não possuísse credenciais válidas para a representação. (ELSTER, 1994.p. 72-74).

${ }^{16}$ Como explica Elster, mesmo quando decisões tomadas por uma corte constitucional ou um banco central não são ineficientes em qualquer dos sentidos técnicos do termo - inferioridade de Pareto ou maximização da não utilidade - elas podem estar em desacordo radical com as preferências estáveis de uma grande maioria dos cidadãos. (ELSTER, 2000. p. 165).

17 "The idea of viewing constitutions as acts of self-binding is one for which I have to take some responsibility. For various reasons, I have come to be skeptical of its normative and explanatory value. For one thing, the binding' effect of constitutions is much less constraining than in such paradigm cases of individual self-binding as saving your money in a scheme under which you cannot take it out before Christmas. For another, the 'self that is supposed to bind itself is much more elusive in the collective than in the individual case. Concerning the second point, the idea of self-binding makes somewhat more sense when the constitution is written
} vol.08, no. 03, Rio de Janeiro, 2015. pp. 1602-1628 
A ideia de pré-compromisso constitucional possui, portanto, sua legitimidade agravada pelo fato de que nenhum grupo social detém o direito de, em nome de todos, arrogar-se a representação do interesse geral. O problema que decorre disso é a imposição das Constituições a minorias e a gerações futuras, a partir do interesse da maioria ou da "primeira" geração.

As futuras gerações não possuem poder de barganha, sua única esperança é a de que os constituintes se preocupem com seus descendentes e alguns de seus interesses futuros. Porém, Elster procura salvar aquilo que resta da sua teoria, em seu aspecto da racionalidade imperfeita, ao afirmar que não é possível esperar que assembleias constituintes imperfeitas criem constituições perfeitas que irão lidar com as imperfeições dos futuros políticos. ${ }^{18}$

A partir da admissão de insuficiências em sua teoria, Elster revisitou tópicos de sua tese original em "Ulisses liberto"; contudo, questões significativas ainda permaneceram em aberto. Isso porque, se parece pacífica a necessidade de que uma comunidade se auto imponha certos limites, o problema está na necessidade de que os limites impostos por uma comunidade, em um tempo e um contexto específicos, passem a valer rigorosamente ante as gerações futuras. Gargarella entende que isso seria tão inaceitável quanto a ideia de que Ulisses exigisse que seu filho se acorrentasse ao mastro do navio, como ele veio a fazer (GARGARELLA, 2008 (b). p. 31).

Para os democratas, o principal problema estaria nesse ponto, e Elster acaba por não justificar a possibilidade de uma conduta como a referida. Se, por um lado, é consistente na defesa da escolha racional que subjaz no auto paternalismo, o ato de se acorrentar não provê, por outro lado, uma resposta para a questão da imposição de normas de uma comunidade sobre outras comunidades (minorias) ou para gerações futuras - na verdade, assume que existem sérios riscos de medidas opressoras na confecção da referida prescrição.

Ulisses estava certo daquilo que ele queria escutar, mas não respondeu ao canto das sereias. O exemplo constitucional é paradoxal, pois, se ele fosse se unir às sereias, ele estaria fazendo aquilo que tinha proibido sua tripulação fazê-lo. Porém, na maioria dos casos constitucionais as opiniões diferem entre os cidadãos se a legislação em questão é o tipo de lei que eles queriam em um momento de fundação e se esta é adequada para antecipar condutas futuras.

by the legislature than when it is the work of a special convention. A legislature that writes the ground rules under which future legislatures will operate does at least have the capacity to bind 'itself, in a loose sense of that term." (ELSTER, 2006.p. 181)

18 "There is no general set of conditions that ensures success in the bootstrap-pulling enterprise of organizing political life. Moreover, succes in the constitution-making stage may lead to failure in the next stage of implementing the constitution." (ELSTER, 1994.p. 82) 


\section{A IMPORTÂNCIA DOS DESACORDOS}

Para Waldron, tantos juízes como parlamentares sabem que, no exemplo constitucional, o problema que eles estão enfrentando é sobre a discordância entre pessoas. Na Odisseia os membros da tripulação sabiam que Ulisses acorrentado era o resultado de uma decisão patológica, compreendida por todos os envolvidos, inclusive o próprio Ulisses.

Existem perigos em uma analogia simplista entre a autonomia racional de indivíduos e o governo democrático de uma comunidade. A ideia de que a sociedade que se acorrenta a certo conjunto normativo é problemática em casos em que os membros discordam entre si sobre a necessidade de tais amarras, ou se eles concordam em termos abstratos sobre a necessidade delas, mas discordam sobre seu conteúdo ou suas características (WALDRON, 1999).

O fato de as normas constitucionais serem constitutivas não remove a possibilidade de revisões democráticas. Waldron afirma que as democracias normalmente revisam as regras do jogo, e isso ocorre mediante debates, discordâncias, como pode ser observado em posições majoritárias que não são unânimes, em votos parlamentares ou em decisões judiciais (WALDRON, 1999 (b)).

As normas constituintes demandam que uma democracia não mude as regras do jogo durante a partida, enquanto o jogo está sendo jogado. As normas das eleições não podem ser mudadas no meio do processo eleitoral. ${ }^{19}$ Mas as pessoas possuem desacordos que passam pelo conteúdo e pela forma das regras, e isso se apresenta como um problema que pode ser agravado, especialmente nos casos em que tais desacordos não parecem possuir meios para um entendimento no futuro.

Quais são os problemas do modelo do pré-compromisso? Quais são as limitações desse modelo ao procurar caracterizar os direitos constitucionais? Isso levaria ao abandono do controle de constitucionalidade e

\footnotetext{
${ }^{19}$ No Brasil pode ser observada a decisão do Recurso Extraordinário 633703, de relatoria do Ministro Gilmar Mendes, em 23/03/201 1, em que a Lei Complementar n. 135/2010, a Lei da Ficha Limpa, não foi aplicada no pleito de 2010 ante a violação do artigo 16 da Constituição Federal, o qual garante a anterioridade (ou a anualidade) da lei eleitoral. Por seis votos a cinco o STF decidiu dar provimento ao recurso de um candidato a deputado estadual de Minas Gerais que teve seu registro negado. No acórdão ficou estabelecido que: "A fase pré-eleitoral de que trata a jurisprudência desta Corte não coincide com as datas de realização das convenções partidárias. Ela começa muito antes, com a própria filiação partidária e a fixação de domicílio eleitoral dos candidatos, assim como o registro dos partidos no Tribunal Superior Eleitoral. A competição eleitoral se inicia exatamente um ano antes da data das eleições e, nesse interregno, o art. 16 da Constituição exige que qualquer modificação nas regras do jogo não terá eficácia imediata para o pleito em curso. (...) Toda limitação legal ao direito de sufrágio passivo, isto é, qualquer restrição legal à elegibilidade do cidadão constitui uma limitação da igualdade de oportunidades na competição eleitoral. Não há como conceber causa de inelegibilidade que não restrinja a liberdade de acesso aos cargos públicos, por parte dos candidatos, assim como a liberdade para escolher e apresentar candidaturas por parte dos partidos políticos. E um dos fundamentos teleológicos do art. $16 \mathrm{da}$ Constituição é impedir alterações no sistema eleitoral que venham a atingir a igualdade de participação no prélio eleitoral. (...) O princípio da anterioridade eleitoral constitui uma garantia fundamental também destinada a assegurar o próprio exercício do direito de minoria parlamentar em situações nas quais, por razões de conveniência da maioria, o Poder Legislativo pretenda modificar, a qualquer tempo, as regras e critérios que regerão o processo eleitoral. A aplicação do princípio da anterioridade não depende de considerações sobre a moralidade da legislação.”.
} 
dos direitos constitucionais? Certamente esta não é a intenção em questionar o pré-compromisso como modelo de compreensão da estrutura constitucional, eis que direitos fundamentais e o controle de constitucionalidade podem ser articulados para além de tal estrutura.

Waldron propõe que se imagine o caso de um apostador compulsivo que sabe que nos seus piores momentos gasta todo o seu dinheiro. O dilema do apostador está no fato de que os caixas eletrônicos podem, em tese, disponibilizar dinheiro para ele 24 horas por dia e os Cassinos estão interessados que os apostadores compulsivos gastem todo o dinheiro que possuem. Contudo, na vida real, os caixas possuem limites diários para o saque, limites que, em um momento de "racionalidade", o próprio apostador coloca em sua conta (WALDRON, 1999. p. 533-534). Ulisses e o jogador compulsivo vivem o mesmo dilema, eles decidem em um determinado momento anterior colocar limites sobre suas próprias ações sabendo que serão seduzidos e não poderão agir de maneira racional no futuro. ${ }^{20}$

Porém, limites constitucionais se apresentam de diferentes formas, como, no caso do devido processo legislativo, em que, para a edição de uma nova lei, o parlamento precisa seguir determinado conjunto de procedimentos estabelecidos anteriormente, observar quóruns, ser submetido a diferentes comissões, em suma, respeitar as formas, a própria gramática legislativa (WALDRON, 1999. p. 535). Se tal estrutura não fosse observada seria criada uma desnecessária dificuldade para atestar a validade da produção legislativa - ponto distinto e muito mais simples do que aquele que releva a artificialidade das autorizações autoconferidas nos momentos de origem.

Aquilo que Waldron (1999) está a enfatizar é que o processo legislativo é permeado por controvérsias, pela inevitabilidade de desacordos: os processos legislativos deveriam ser levados a sério, mesmo ante o possível equívoco de enfatizar apenas substâncias em detrimento de formas. ${ }^{21}$

A produção legislativa não pode ser vista como apenas o exercício de um poder, há a importante transição, mediação, entre a moralidade pública de uma determinada comunidade e sua tradução em formas burocráticas que possam torná-la pública e ajustada a um sistema normativo. O ato legislativo, em sua faceta instrumental, almeja representar as subjetividades, as consciências daqueles que compõem o povo em termos objetivos - tal processo possui, por óbvio, distorções e patologias que acabam por ser enfatizadas como o principal aspecto do legislativo. ${ }^{22}$

\footnotetext{
${ }^{20}$ Antes de ser uma "estranha metáfora", o exemplo do apostador é um desafio para a teoria da escolha racional, pois expõe os limites da normatividade imbricada nesta teoria.

21 "In fact, there are three kinds of principles that might be relevant to the legislative task: (1) substantive principles, like Rawls's or Bentham's; (2) formal principles, that is, principles having to do with the form of legislation, like Fuller's; and (3) procedural principles, having to do with the institutions and processes we use for legislation." (WALDRON, 2006.p. 17).

${ }^{22}$ Waldron lista 7 princípios que contribuem para a configuração da produção legislativa: 1 - a ideia de que a produção legislativa é explícita, tem-se uma instituição dedicada publicamente para esta tarefa, embora a produção legislativa pelas Cortes seja reconhecida, a produção legislativa por meio da jurisdição não se apresentaria como um processo público para a criação ou vol.08, nº. 03, Rio de Janeiro, 2015. pp. 1602-1628 1614
} 
Ainda que o Congresso procure aprovar uma lei, sua validade pode ser testada pelo Judiciário, logo, a lei pode ser declarada inconstitucional e não ser aplicada. Os limites do próprio sistema normativo apresentam-se como o limite de saques do caixa eletrônico do apostador compulsivo. As restrições constitucionais e o controle de constitucionalidade são institutos necessariamente controversos, ante suas funções em face do ideal democrático, da autodeterminação. ${ }^{23}$

O problema é que a metáfora de Ulisses é uma tentativa de reconciliar o autogoverno e o sistema de limites constitucionais mediante uma perspectiva que "desabilita", que se limita a constranger um dos polos em tensão. O pré-compromisso turva a própria necessidade basilar de serem realizados compromissos ao longo da história constitucional, na narrativa ininterrupta que almeja ser traçada por uma democracia constitucional.

O solipsismo de Ulisses não espelha apenas um domínio da razão sobre as paixões, mas, também sobre as contingências, sobre potencialidades por serem descobertas, eliminadas em sua origem, bem como sobre a

alteração das leis; 2 - os legisladores possuem o dever de precaução em relação à produção legislativa, uma vez que as leis produzem consequências reais e podem gerar injustiças para pessoas reais, além disso, a produção de uma nova lei afeta todo o corpo legislativo, por isso, precisam prestar atenção tanto para a nova lei, bem como para os efeitos desta no sistema normativo, ante os interesses e direitos dos cidadãos; 3 - por mais importante que a inovação legislativa seja e por mais que a lei esteja bem feita, espera-se que ela seja submetida a debates, escrutínio, e decisões por assembleias, as quais devem representar uma grande diversidade de opiniões e interesses; 4 - deve haver respeito pelo desacordo, pois, os corpos legislativos são instituições constituídas para permitir que perspectivas radicalmente distintas de mundo sejam debatidas, de modo que todos aqueles envolvidos na produção legislativa possam ouvir e ser ouvidos, trata-se de uma "oposição leal"; 5 - o debate demanda uma abertura para outras perspectivas e razões, o legislativo não é um lugar apenas de "aparências", mas de discussões, por isso, é importante que exista uma abertura para que as partes possam mudar de opinião, para que os argumentos possam ser elaborados, corrigidos, modificados ao longo do processo legislativo; 6 - a diversidade política dentro do legislativo é garantida pelas características formais relacionadas com os processos políticos, a preocupação com o sistema eleitoral, a composição do legislativo, regras sobre partidos e procedimentos para deliberação são indicativos disso, as formalidades asseguram que a reunião de pessoas distintas que não se compreendem muito bem funcione; 7 - a regra da maioria é utilizada para determinar se a lei foi ou não adotada, não se trata de defender a regra da maioria em específico, mas observar como ela é utilizada como uma condição para respeitar a igualdade política no processo legislativo, os representantes possuem a demanda derivativa de que eles devem ser tratados de forma igual, mas, isso, para Waldron, só existe pelo fato de que os muitos, os representados, podem demandar o tratamento igualitário, por isso, a igualdade é derivativa, depende dos votos dos eleitores. (WALDRON, J. 2006. p. 22-30).

${ }^{23}$ Gargarella sugere que a democracia deliberativa seria uma maneira de equacionar tal problema: "What are the implications of adopting a deliberative view of democracy for understanding the proper role of the judiciary? First of all, I believe that a deliberative view would reject the conventional wisdom that judges should have the 'final say' about the meaning of the Constitution. In particular, a deliberative conception of democracy would reject judicial supremacy (as opposed to judicial review), since it assumes that all important constitutional matters should be open to ongoing discussion among all affected parties. This principle conflicts with the idea of courts having a privileged role in these discussions. Democratic deliberation requires that, in principle, all participants take part in collective debates about basic constitutional matters, and that the people as a whole retain the 'final say' in all these matters. ( ... In my opinion, when we accept that judges are subordinate to - indeed servants of - public debate, then we may begin to see the judiciary as a crucial engine of public debate. In effect, judges are exceptionally well situated for fulfilling this task, because their principal function is to receive complaints from all those who are marginalized or severely affected by the decisions of the political branches. Institutionally speaking, the judiciary represent the main channel that disadvantaged groups have for becoming heard, when the political branches refuse to hear or unduly dismiss their claims. Judges are exceptionally well placed to require a better justification of their decisions from the people and their representatives." (GARGARELLA, 2006. p. 28). vol.08, n. 03, Rio de Janeiro, 2015.pp. 1602-1628 1615 
temporalidade. O próprio ser racional atado no mastro do navio aposta contra si mesmo, sabe dos limites da racionalidade, dos futuros ressentimentos que esta pode produzir. ${ }^{24}$

Mas não há nada de novo em sugerir uma racionalidade imperfeita, limitada, pela simples percepção de que seu oposto é indefensável. Para Waldron, os arranjos realizados por Ulisses ou pelo apostador não deveriam ser compreendidos como uma renúncia à liberdade individual, mas sim a epítome do autogoverno, pois a liberdade não pode ser restrita à observação das intenções subjetivas de um sujeito, mas deve abranger o controle (e responsabilidade) de suas ações (WALDRON, 1999.p. 540).

Quais os motivos para que alguém venha a se autolimitar ou querer projetar o seu controle presente sobre gerações futuras? De acordo com Waldron, a resposta para isso está pautada no medo de legislações majoritárias, maiorias populares podem ser conduzidas a adotar medidas que ferem minorias que não possuem proteção institucional para resistir contra elas. ${ }^{25} \mathrm{~A}$ oscilação entre momentos de racionalidade e irracionalidade pode ser observada no âmbito individual como no plano coletivo, ${ }^{26}$ mas aquilo que parece faltar para tais miradas é justamente a articulação entre as duas esferas, entre a consciência derivada da comunidade política e o papel dos indivíduos na organização desta, na ausência de uma sociedade "sem indivíduos".

No âmbito constitucional não se trata de uma pessoa decidindo sobre suas correntes, mas de um agente coletivo complexo que, de maneira contingente, decide um determinado conjunto de predicados políticos que serão postos em funcionamento. Uma das facetas mais complicadas do constitucionalismo negativo (proteção de garantias aos indivíduos em sua relação com o Estado) é a da possibilidade de se condenar a democracia a uma condição de imobilidade. Tal condição poderia fazer com que o povo fosse pensado como um conjunto de indivíduos erráticos, e não como uma entidade, uma instituição, um corpo, que continua a perdurar por diferentes gerações.

\footnotetext{
${ }^{24}$ Um desafio que Ulisses dificilmente poderia resistir é aquele apresentado pela excepcionalidade. Ainda que dispositivos constitucionais procurem dispor (racionalmente) sobre os casos de exceção, a história indica que a exceção se torna permanente e que, por mais que a exceção, no início acabe por se apresentar na forma comissária, ela quase sempre acaba por assumir a modalidade soberana. Em outros termos, ainda que as amarras constitucionais possam ser usadas para tentar conter a akrasia política, os momentos patológicos da democracia, ela dificilmente terá algum sucesso, uma vez que em momentos de alta intensidade política a democracia se apresenta "sem forma", contesta e redefine as estruturas políticas da sociedade.

25 "So if constitutional constraints and mechanisms of judicial review are set up by popular decision, they may be viewed as precautions which responsible right-holders have taken against their own imperfections. Such precautions do not therefore involve any fundamental disrespect from the people or their capacities of self-government. On the contrary they represent the epitome of those capacities in a troubled and complicated world." (WALDRON, 1999 (b).p. 258).

${ }^{26} \mathrm{~A}$ liberdade moral, a ideia do livre relacionamento do indivíduo com si próprio, é a ideia de um sujeito que se coloca atrás ou acima de seu ato, que é responsável pelo ato pelo fato de poder ter agido de outra forma. Ulisses é a imagem da auto-repressão, condição importante para a individuação, a repressão das pulsões de vida que fazem parte da constituição da subjetividade. Nos termos de Adorno: "The freedom he must look forward to could not be his alone; it would have to be the freedom of the whole. A critique of the individual leads as far beyond the category of freedom as that category has been created in the unfree individual's image. The contradiction that for the individual sphere we can proclaim no free will, and thus no morality, while without them there is no preserving even the life of the species (...) Freedom, which would arise only in the organization of a free society, is sought precisely where it is denied by the organization of the existing society: in each individual. The individual would need freedom, but as he happens to be, he cannot guarantee it." (ADORNO, 1976. p. 275-276).
} 
A ausência da abertura para reconsiderações das estruturas normativas fundamentais da comunidade política a condenaria, no pior dos cenários, à exclusão de novos membros, uma vez que esta é uma das características da comunidade que está em constante transformação e precisa ser (re)considerada periodicamente pelo constitucionalismo. Além disso, a questão intergeracional também expõe os limites da possibilidade de um constitucionalismo imobilizado.

Nos termos de Waldron, o pré-compromisso deixa de ser o símbolo do triunfo da racionalidade antecipadora que se apresenta no caso de Ulisses e do apostador. Ao contrário, ela é o domínio de uma perspectiva política mantida artificialmente em detrimento de outras, sobre os temas complexos que determinam a comunidade e que não são completamente resolvidos (WALDRON, 1999.p. 551).

Ante o ato de investidura do poder de decisão para uma pessoa ou para um conjunto de pessoas, como uma Corte, cujo trabalho é determinar se a conduta é contemplada, acaba por ser o julgamento de se, uma determinada conduta, uma nova lei, adequa-se ante as amarras (constitucionais) estabelecidas anteriormente. Por isso, o pré-compromisso funciona como a inferência de acordos anteriores de uma comunidade política que, em suas práticas cotidianas, é marcada por desacordos e diferentes compreensões da realidade.

Uma vez que esse cenário é reconhecido, pode-se observar o anverso da imagem de um suposto acordo ou consenso definitivo, o qual procura dar continuidade e (artificialmente) constituir a realidade social. Fazem-se possíveis a revisão, o abandono de práticas anteriores, a acolhida de novas situações em que renovados compromissos podem ser realizados. Por isso, os desentendimentos, os desacordos não são observados como um "canto de sereia", como uma forma patológica, mas como constitutivos do ethos da política, de uma comunidade preocupada com a democracia, com a possibilidade da autodeterminação.

Waldron alerta para uma confusão recorrente que pode ser realizada entre democracia e soberania popular, enquanto esta abrange um princípio fundamental para o pensamento liberal ao demandar que o povo tenha a possibilidade de decidir sobre sua própria constituição, escolher a forma de governo que ele considera mais adequada para conduzir suas atividades políticas, ela não pode ser confundida com os diferentes instrumentos de governo disponíveis para que o povo possa escolher como ser governado (WALDRON, 1999 (b).p. 255).

A vantagem das "amarras" estaria no fato de elas operarem de forma "rígida", embora deixem um espaço para o julgamento, para a reflexão dos seus operadores. $\mathrm{O}$ aspecto falho delas estaria no fato de que as amarras poderiam passar a servir propósitos que não representam as intenções daqueles que as criaram no momento inicial. Como ressalta Waldron, se uma agente "A" conferiu, investiu, transmitiu seus poderes de decisão, de julgamento para um outro agente "B", com algum espaço para que "B" possa julgar, tal gesto poderia ser questionado se foi a realização de um efetivo pré-compromisso por parte de "A". 
Considere o exemplo de uma pessoa (“A") que, em um primeiro momento (t1) entrega para outra ("B") o poder de decidir no futuro ( $\mathrm{t} 2$ ) sobre alguma ação em sua vida, sua propriedade, ou mesmo sobre o seu papel (“A”) na sociedade. O segundo agente ("B") tem o poder de decidir - e pouco pode ser feito para conter em termos absolutos tal poder -, por exemplo, plantar milho na propriedade de "A" ao invés de soja; decidir onde ele irá passar férias ou se ele irá tirar férias; substituir "A" no parlamento, se "A" for Senador e "B" seu suplente.

Tais casos são diferentes da relação em que "A" confere uma ordem específica para "B", dizendo, para este, na condição de seu procurador, comprar um carro, especificando todos os detalhes do automóvel, as condições de pagamento, a forma de retirada do automóvel. Contudo, se carros amarelos não são mais produzidos e "A" pediu um carro de tal cor, "B" precisará decidir se ele vai comprar o carro de outra cor ou deixar de comprar o carro.

Ainda que "A" tenha decidido, de maneira autônoma - de acordo com seu próprio nomos -, que iria transferir para "B" o poder de decisão, a consumação, a operacionalização deste poder dificilmente pode ser vista como a consumação de sua autonomia original, pois trata-se do julgamento de "B" em seu lugar (WALDRON, 1999 (b).p. 262).

O problema no modelo do pré-compromisso é que ele poderia tratar apenas do caso em que "A" transmite uma decisão que é quase completamente fechada, uma decisão sem espaço para qualquer julgamento por parte do representante. Aquilo que "B" pode tornar presente é apenas uma vontade do passado, uma artificialidade, um passado reapresentado. $\mathrm{O}$ risco de tal autoautorização está na imobilização das relações da comunidade política ou no artifício de tornar vivo o passado.

Tal disposição não garante que " $\mathrm{B}$ " irá tomar as melhores decisões no lugar de " $\mathrm{A}$ ". Isso pode ser visto no espectro mais amplo da política em que representados clamam não terem seus interesses devidamente feitos presentes por seus representantes, além disso, em casos extremados "B" pode decidir subverter todo o regime político e adotar medidas opostas àquelas que ele foi designado para representar.

Diferentes exemplos podem ilustrar a dificuldade constante no momento t2, um caso que enfatiza as paixões e os interesses é o do motorista precavido que sabe que irá consumir álcool, vai deixar de ser movido pelos interesses e vai passar a ser um "agente" irracional e entrega as chaves do carro para um amigo abstêmio que não sabe dirigir. No caso de uma emergência, em que o motorista precavido precisa dirigir bêbado, o précompromisso não apresenta qualquer resposta. ${ }^{27}$ No exemplo do carro comprado por "B", imagine-se que "A" ao invés de especificar a cor pede o "carro mais bonito". Ocorre a delegação do poder para a realização de um juízo estético. Tem-se um princípio genérico que precisa ser objetivado por outra pessoa.

\footnotetext{
27 "Constitutional constraints may be seen as prophylactics against political akrasia - that is, against the pathology of anger, panic, or greed that is often thought to be endemic in democratic politics." (WALDRON, 1999 (b).p. 266).
} 
A necessidade de julgamentos, de juízos não pode ser compreendida se não for assumido que eles poderão ser corretos, adequados em certas circunstâncias em termos não previstos anteriormente. $\mathrm{O}$ exercício do juízo demanda um espaço de imprevisibilidade, pois, em outro cenário, não seria necessária qualquer reflexão, se os julgamentos pudessem ser antevistos, as decisões constitucionais estariam próximas de um exercício mecânico de iuris dicere, uma jurisdição ex ante (WALDRON, 1999 (b). p. 263). Além disso, não poderiam subsistir controvérsias quanto à aplicação do direito. O que é bastante contraintuitivo, uma vez que aquilo que se espera da inferência de aplicações particulares de princípios complexos é justamente o desacordo. ${ }^{28}$

A ideia de uma comunidade política demanda que seus cidadãos sejam reconhecidos como membros para dar continuidade ao projeto, às estruturas do passado. Logo, se as gerações anteriores definiram um determinado conjunto de instituições relevantes para a organização e condução da política, aquilo que se apresenta, em um primeiro instante, como natural é que este projeto seja continuado pelas gerações futuras.

O pré-compromisso supõe sua extensão ao longo do tempo, se pretende perene, para além de seus criadores. Contudo, como afirma Waldron, agora, o presente, parece ser o momento certo para evitar que futuras violações ocorram; porém, nem sempre aqueles que produzem as legislações que "amarram” o presente conferem a abertura para que o "futuro" possa ser redefinido. ${ }^{29}$ A questão é que as próprias "amarras" podem ser colocas em questão. Enquanto, por um lado, elas conferem um instrumental, indicam procedimentos como a forma da eleição presidencial, por outro, elas não possuem respostas para o caso em que a própria forma política é questionada, se o presidencialismo pode ser substituído pelo parlamentarismo.

Em perspectiva diversa da sugerida por Holmes, Waldron explica que ainda que alguma forma de democracia deliberativa seja defendida pela perspectiva majoritária, as opiniões sobre os diferentes modelos de deliberação são plurais. Democratas discordam sobre os temas mais distintos como as formas de representação política, a possibilidade de reeleição, o financiamento de campanhas.

As pessoas, por sua vez, divergem sobre temas plurais como: a extensão da liberdade de expressão; até onde o interesse público pode interferir na vida privada dos indivíduos; a possibilidade de discursos de ódio na esfera pública, além de outros temas considerados relevantes para a comunidade política (WALDRON, 1999 (b). p. 279).

\footnotetext{
28 "In other words, in the constitutional case we are almost always dealing with a society whose members disagree in principle and in detail, even in their 'calm' or lucid' moments, about what rights they have, how those rights are to be conceived, and what weight they are to be given in relation to other values. They need not appeal to aberrations in rationality to explain or characterize these disagreements. (...) Clearly there are dangers in any simplistic analogy between rational autonomy of individuals and the democratic governance of a community. The idea of a society binding itself against certain legislative acts in the future is problematic in cases where members disagree with one another about the need for such bonds, or if they agree abstractactly about the need but disagree about their content or character." (WALDRON, 1999 (b).p. 268-269).

29 "A bunch of individuals must constitute themselves as a people - that is, as a political community - even in order to frame a constitution. But mostly what they do in their framing is construct what they hope will be an eduring set of institutions which can embody decision procedures and mechanisms of collective action." (WALDRON, 1999 (b).p. 275).
} 
Assim, enquanto Elster e Holmes percebiam e enfatizavam a constituição (passada) da comunidade política, Waldron procurou privilegiar a sequência dos compromissos produzidos na comunidade política, em contínuas práticas políticas e constitucionais, nas quais os desacordos irão sempre reemergir. ${ }^{30}$

\section{SOBRE COMPROMISSOS, AÇÃO POLÍTICA E CONSTITUINTE}

A regra da maioria é uma forma de operacionalizar o imperativo democrático do governo pela vontade dos vivos. Nessa perspectiva, a autodeterminação, a autonomia do povo define um conjunto de preferências, julgamentos, valores - estas irão definir o modo como a vida das pessoas poderá ser conduzida. A estrutura que organiza a comunidade política define também a vida dos cidadãos, que possuem inscrições, registros, produzidos para além de sua esfera pessoal de liberdade.

Como anota Rubenfeld, a maioria das pessoas vive e reproduz compromissos realizados em diferentes graus, no âmbito público e privado, mas não se questionam a todo instante sobre aquilo que elas deveriam fazer. Vive-se sob os termos de compromissos, no trabalho, na família, na política, na religião sem que se questione a todo instante ou se atualize a todo momento tais arranjos (RUBENFELD, 2003. p. 1759).

Aqueles que procuram a autodeterminação não buscam um estado de anomia, almejam conjugar o governo do passado e o autogoverno. A legitimação serviria para tratar os acordos do passado como presentes, é uma das formas pelas quais as externalidades podem ser internalizadas, mas, também, é sob sua sombra que novos compromissos podem ser realizados na arena política. Assim, o constitucionalismo, afirma Rubenfeld, não se opõe à democracia, pode ser democrático através do tempo. O constitucionalismo é uma instituição por meio da qual uma comunidade democrática procura tecer compromissos que irão definir quais são suas características legais e políticas, e isso implica autogoverno (RUBENFELD, 2003.p. 1761).

Ao contrário dos representantes democraticamente eleitos, os juízes ocupam outro papel, representam outro aspecto da máquina institucional. Os magistrados não respondem (necessariamente) às opiniões populares, à vontade do povo. O princípio da independência do Judiciário procurou garantir este status no processo de formulação de juízos, dos julgamentos pelos juízes. ${ }^{31}$ Para Rubenfeld, eles não representam o povo presente, (RUBENFELD, 2003. p. 1762) desta geração. Esta tarefa é própria dos políticos e dos administradores públicos, dos representantes eleitos. Aos magistrados cabe a tarefa de observar os compromissos que a comunidade política conferiu para si mesma, ainda que tais compromissos não sejam mais apreciados pela maioria do povo.

\footnotetext{
30 "All this is surely healthy; it is exactly what we should expect; and we may describe it - for the purposes of legal and political philosophy - in any number of ways. But one thing, it seems to me, we cannot say: we cannot describe this process in terms of a set of a unequivocal popular precommitments to a particular form of political decision-making. How to make collective decisions in politics? - all we can say is that this is something we are continuing to work on." (WALDRON, 1999 (b).p. 280).

${ }^{31}$ Sobre o tema ver: CLÈVE, 2013.
} 
A conjugação da liberdade com o discurso não é um caso fortuito, a liberdade de expressão emerge nos contextos em que a liberdade foi usada como o ideal do governo dos vivos, dos presentes (RUBENFELD, 2001. p. 04). Este ideal expressa a tarefa (impossível) de seguir apenas a própria voz, os próprios discursos e vontades. Por isso, a liberdade política se põe em contenda com as escrituras do passado, as inscrições que nos governam (escritas e não escritas) - por isso a tensão entre a liberdade e a democracia e o constitucionalismo.

As revoluções (americana e francesa) ao mesmo tempo em que procuraram fundar a modernidade foram movidas pelo direito dos vivos, o direito do autogoverno daqueles que estavam presentes. A "vitória" dos revolucionários foi, com a diferença de valores e contextos, a criação de um espaço próprio para o povo, para o "nós", para a voz do povo, que se projetou como forma das futuras gerações. Por isso, instituições foram criadas para preservar, de maneira paradoxal as potências do passado.

A proposta de Rubenfeld é a de restaurar a temporalidade da democracia. Ao invés de antepor a vontade presente dos vivos e as verdades atemporais dos mortos, pode-se considerar que o povo vive sob os termos de seus próprios compromissos políticos e legais tecidos ao longo do tempo. Isso porque a tensão entre o constitucionalismo e a democracia se apresenta quando o povo procura afirmar sua vontade no presente, mas o constitucionalismo pode ser democrático em uma temporalidade estendida, ou pode prometer ser democrático ao longo do tempo (RUBENFELD, 2001.p. 12).

Por isso, não é suficiente que a Constituição tenha sido produzida ante a observância de procedimentos democráticos - ainda que possam subsistir dúvidas sobre a origem dos próprios procedimentos. Aquilo que é fundamental, é o modo como se vive, como as pessoas têm a vida conduzida pela Carta de Direitos, eis que deve existir uma abertura para que seu texto possa ser reescrito.

A precedência democrática é uma condição de possibilidade para que futuras promessas possam ser realizadas, mas não é condição suficiente, pois, por mais "perfeito" e "único" que o momento de fundação tenha sido, ele não é suficiente para dar continuidade à tensão entre constitucionalismo e democracia. ${ }^{32}$

Ainda que seja um gesto importante, a celebração periódica do acordo passado que reuniu um povo sob a regência de uma Constituição, precisa ser suplementado, continuado. A modernidade demanda que se aprenda a viver no presente (ou na representação daquilo que se faz presente), a enfrentar a autodescoberta, a reflexividade da própria modernidade. ${ }^{33}$

\footnotetext{
32 "To say in 1789 that 'the earth belongs to the living' was not only to justify the American and French Revolutions, freeing the present, indeed urging the present, to cast off the dead hand of the past. It was also to impugn the tremendous efforts of those who, in the name of those revolutions, on 'either ... side of the water,' were seeking to reach their hands, through law, into the future. To Jefferson in 1789, who could not participate in America's constitutional conventions because he was in France, and who could not participate in France's constitutional conventions because he was American, the very principle that gave legitimacy to those conventions condemned their work as illegitimate." (RUBENFELD, 2001.p. 21).

33 "Modernity's declaration of the present's independence is, therefore, not so much false as fundamentally equivocal. Modernity does possess a 'master-idea' differentiating it from the past - the idea precisely of the present's independence from the past - but vol.08, no. 03, Rio de Janeiro, 2015.pp. 1602-1628 1621
} 
O problema é que a ruptura com o passado não conduz necessariamente a uma vida no presente. Nas revoluções, aquilo que se projetava - entre o hiato de autoridade, autorizações - eram instituições perenes, que continuassem a durar e que fossem herdadas pelas gerações posteriores. Observa-se o esforço democrático de produzir uma Constituição e viver sob os compromissos de fundação ao longo do tempo.

A vontade presente dos governados é a fonte para a legitimação política, de modo que o passado apenas se faz presente se os vivos a reproduzem, o reapresentam na arena política. ${ }^{34} \mathrm{~A}$ autodeterminação não será limitada apenas por escrituras, por inscrições presentes ou do passado. As narrativas do passado precisam ser reapresentadas. Esta é a fórmula que a tradição republicana já conhecia e havia procurado transmitir. Logo, não é apenas do passado, de pré-compromissos que a articulação da comunidade política é realizada, a ação política dos vivos, dos governados precisa legitimar as diferentes temporalidades da autoridade política, que também não podem ser limitadas apenas às vontades dos presentes.

O autogoverno modelado por discursos, pela possibilidade que diferentes discursos possam ser apresentados na esfera pública e possam produzir desacordos, demanda limitações nos meios pelos quais a vontade popular irá ser manifestada. A relação é de uma simultânea e (im)possível adoração e profanação das escrituras constituintes, em uma democracia que procura se fundar em discursos (RUBENFELD, 2001.p. 49). O autogoverno se faz em tempos presentes, em um presente tensionado, é nesta temporalidade que a relação entre o constitucionalismo e a democracia se desenvolve.

Uma perspectiva que se concentre na formação de um consenso no presente acaba por preterir ou diminuir a vontade popular na determinação da tensão. Por isso, entende que o Judiciário é o espaço adequado para falar em nome do povo, ainda que contra o próprio povo. Uma versão aprimorada de tal perspectiva enfatiza que os direitos constitucionais e as instituições que o defendem devem ser entendidas como condições para o estabelecimento e a manutenção do processo democrático (RUBENFELD, 2001.p. 59).

$\mathrm{O}$ procedimentalismo procura legitimar os direitos fundamentais contramajoritários com base na vontade popular presente sem demandar que o Judiciário represente a vontade do povo. Por isso, procura enfatizar as condições constitutivas do discurso público, em que os cidadãos podem dialogar e produzir seu autogoverno. Contudo, observa Rubenfeld, os dispositivos constitucionais são compromissos fundacionais, que tratam de temas substantivos como a justiça, a liberdade e o poder, com o intuito que o povo possa governar seu

this idea can never be concretized, never realized in any institution. Institutions are what persist from one day to the next; they are what hold the present to the past. Hence the wish to escape time's grip must never be materialized, never rendered into a form of life, never concretized, memorialized or institutionalized; it cannot be, without re-entrenching the present into history and thereby reestablishing time's grip." (RUBENFELD, 2001.p. 37).

34 " (...) a basic Derridean insight is inescapable here. The rhetoric of speech and voice marks the operation of a desire for presence. (...). Speech and voice dominate political thought because political thought has embraced the present-tense demand that the living seize the day and seek governance by their own will here and now. Speech, not writing, is the linguistic medium of choice for a self that would live by tis own present will." (RUBENFELD, 2001.p. 47). 
próprio destino. Tais compromissos estendidos não podem ser capturados pela gramática procedimentalista (RUBENFELD, 2001.p. 73).

De modo a preservar sua soberania, o povo precisa escrever suas normas, definir quando irá se reunir em assembleia, definir a data para se constituir ou continuar se constituindo. Porém, o ideal do povo que escreve para si próprio, reencena o problema de fundação, da ausência de autorização para marcar o dia da assembleia popular. A lei que marca o dia do início da assembleia constituinte está baseada em uma lei anterior, a lei que antecede qualquer pronunciamento de autoridade. Por isso, a voz popular não governa sozinha, precisa da escritura, de inscrições, um texto fundacional produzido no passado que antecede a voz da autoridade presente. Se uma busca pela primeira autoridade for realizada, aquilo que será encontrado provavelmente se assimilará a uma ficção, uma vez que tal busca não possui um fim..$^{35}$

Os sistemas normativos sofrem da falha, da falta de uma fonte última de fundação, mas o problema do regresso infinito não é respondido de maneira simples. ${ }^{36}$ Aquilo que nos constitui - os vivos, os senhores do autogoverno - também é perpassado por uma aporia. O "nós", o povo presente, não pode se autoanunciar, não em sua voz presente, precisa sempre pressupor um determinado conjunto prévio, uma gramática, um conjunto de normas, os limites, as margens, aquilo que fica dentro e fora, sem o qual o ideal de um governo popular não se faz

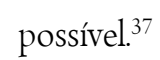

A identidade do sujeito constitucional não se limita a sua herança, a suas características geográficas, suas fronteiras - eis que estas podem ser mudadas - dentro de uma comunidade política (ROSENFELD, 2010). O problema das fronteiras reflete a luta interna sobre a igualdade e o pertencimento.

Essa é a tensão que move a identidade, entre sua definição e sua redefinição, entre as lutas por inclusão de outros - estrangeiros -, e também, daqueles membros internos que não desfrutam da igualdade como outros cidadãos. Pode-se falar das margens internas da própria comunidade em que características como raça, gênero,

\footnotetext{
${ }^{35}$ The regress problem is meant to highlight the impossibility of providing "ultimate" foundations for any legal order. The regress problem is said to show that no political-legal order can be founded without some kind of law-less act, some instituting act of force that cannot be justified without circularity or without assuming the existence of normative foundations that cannot themselves be ultimately grounded. (RUBENFELD, 2001.p. 77)

${ }^{36}$ Para Kelsen, o fundamento de validade da norma se encontra em outra norma: esta é a relação entre supra e infraordenação. Tem-se, com isso, um sistema hierárquico de normas centralizado pelo Estado. A unidade do sistema é garantida pela relação entre as normas superiores e inferiores, a qual leva até a norma última, a norma fundamental: o fundamento supremo da validade do ordenamento jurídico que constitui sua unidade. A norma fundamental é pressuposta, enquanto a Constituição ocupa o posto mais elevado do sistema normativo. A Constituição é percebida não no sentido formal mas material. Nos termos de Kelsen: "Tal forma especial para leis constitucionais, uma forma constitucional, ou constituição no sentido formal do termo, não é indispensável, ao passo que a constituição material, ou seja, as normas que regulam a criação de normas gerais e - no Direito moderno - normas que determinam os órgãos e o processo de legislação, é um elemento essencial de todas as ordens jurídicas." (KELSEN, 2000. p. 182).

37 “If there were no prior determination of this we inscribed already into a nation's institutions, we would be unable to speak now at all. For the will of the governed to govern today, we must have more than constitutionally marked days. We must also have - we must also be - marked men." (RUBENFELD, 2001.p. 80).
} 
idade, religião irão compor um determinado contexto, mas precisam ser testadas, desafiadas, em um processo de iteração (BENHABIB, 2006).

O "nós" está a espelhar um determinado conjunto de características que formam a identidade, mas esta, cuja pretensão é governar o presente, não pode tratar da sua própria vontade presente sem o arranjo institucional que promove classificações, sem as operações anteriores que definem, por exemplo, as formas da igualdade. Um determinado conjunto de princípios já está estabelecido para que a identificação da vontade presente do "povo" ocorra.

O autogoverno produz uma antinomia em seu próprio cerne e, ao mesmo tempo procura ir além dos domínios do autogoverno democrático, para responder às questões substantivas que organizam a comunidade política, tais como a definição de justiça, igualdade, cidadania. Porém, tais questões ficam sem uma resposta se a vontade dos vivos for observada como um pequeno instante temporal e não uma temporalidade estendida. ${ }^{38}$

Tal equívoco pode ser cometido tanto no que tange ao presente como o passado. A idealização do momento constituinte a um momento "superior" quase "fora da história" que o povo se constituiu não pode ser vista como uma conquista do autogoverno, não naquele momento, pois, um momento fundacional, em que o povo declara sua própria independência e sua própria Constituição, vive o conflito da sua inexistência anterior (DERRIDA, 2002).

O momento originário, se alguma vez este momento se fez presente, só poderia ser produzido como um projeto futuro, como "eles serão", com um futuro perfeito que pretende ser realizado; trata-se de ações que "terão sido feitas" ou que "deveriam ter sido realizadas". O momento fundacional, que expressa, representa a voz do povo deveria ter sido como um performativo, como aquilo que traz em si mesmo as próprias convenções que pode realizar. Como observa Rubenfeld, esta extensão temporal, a projeção de um futuro perfeito não está apenas no momento de fundação, esta é a marca que todo ato legislativo carrega consigo (RUBENFELD, 2001.p. 85).

Uma lei que é inserida em um ordenamento jurídico no momento tl, de acordo com a vontade da maioria manifestada neste instante ( $\mathrm{t} 1$ ), continua a ser aquilo que ela era anteriormente? Ela terá sido uma lei apenas em um momento posterior, t2, é isto que toda a produção legislativa, todo ato que se autodenomina lei, precisa sustentar, uma continuidade, uma estrutura temporal para além do ato, do evento, do instante. Como afirma Rubenfeld: "Para que exista o direito, deve haver uma continuidade., ${ }^{39}$ uma reunião, uma decisão, uma estrutura que sustenta, que mantém o tempo, os acordos, uma restrição, um prolongamento.

\footnotetext{
38 "The struggle for law that every democracy must wage is struggle in which force, reason, and present popular will all figure, but in which there may also unfold an effort that exceeds every one of these terms. This is the effort by which a people would remake the state, over time, in the light of its own self-given political commitments." (RUBENFELD, 2001.p. 83-84).

39 "For there to be law, there must be a holding." (RUBENFELD, 2001.p. 85). Tradução livre.
} 


\section{CONCLUSÃO}

O direito precisa, portanto, de ao menos dois tempos: um em que as leis são criadas e outro em que elas são mantidas, continuadas. Porém, tal binarismo é limitado, eis que o direito se apresenta na continuidade, no excesso da temporalidade presente. $\mathrm{O}$ direito excede o aqui e agora e isso pode ser observado na prática do autogoverno, concertada pela pluralidade de discursos que procuram representar diferentes temporalidades, por isso, o direito existe ao longo do tempo.

O povo procura, portanto, de diferentes maneiras sua autonomia, determinar os modos em que poderá ou deverá ser, mas isso só pode ser realizado em um contínuo temporal. As atividades de um povo não podem ser limitadas a um momento. Eis que aquilo que um povo, que possui a liberdade como um valor substantivo em sua autodeterminação almeja ou pretende fazer pode levar várias gerações para ser realizado. A igual proteção fornecida pelas leis, ainda que seja uma demanda urgente, um apelo que afeta diretamente a vida das pessoas, é algo que demanda tempo, instituições, embates, dissensos para que possa vir a ser realizada. ${ }^{40}$

É nessa tessitura que se pode falar de compromissos como razões para a ação política, de maneira distinta dos pré-compromissos. Alguém que é comprometido com uma determinada causa, com um determinado conjunto de ideias, com princípios, possui razões para agir, para dar vida a distintos projetos. Está a conduzir um governo, um navio distinto daquele de Ulisses, cuja racionalidade é pautada pela dicotomia entre a sobriedade e as paixões. Os compromissos se projetam como um potencial para agir no futuro e não como amarras do presente.

Precisa-se procurar os sentidos daquilo que o ato de as pessoas conferirem normas para si mesmas representa, uma vez que criar um conjunto normativo dista a imagética do pré-compromisso ante sua aridez temporal. Mas qual seria, então, a explicação para aquele conjunto de dispositivos, de instituições, de ideias, de valores que nos precedem, aquilo que pode ser chamado de cultura ou civilização (Kultur)? $?^{41}$

\footnotetext{
40 "Self-government cannot be an exercise merely of the freedom of speech and all that the freedom of speech entails ( ...). Selfgovernment requires an inscriptive politics, a politics that exercises the freedom to write, a politics oriented around the production and enforcement of a democratic text laying down enduring principles and institutions for generations to come." (RUBENFELD, 2001.p. 86).

${ }_{41}$ "These things that, by his science and technology, man has brought about on this earth, on which he first appeared as a feeble animal organism and on which each individual of his species must once more make its entry ('oh inch of nature') as a helpless suckling (...) All these assets he may lay claim to as his cultural acquisition. Long ago he formed an ideal conception of omnipotence and omniscience which he embodied in his gods. To these gods he attributed everything that seemed unattainable to his whishes, or that was forbidden to him. One may say, therefore, that these gods were cultural ideals. Today he has come very close to the attainment of this ideal, he has almost become a god himself. (...) Man has, as it were, become a kind of prosthetic God." (FREUD, 1962. p. 38-39). Nos termos de Legendre, a submissão se torna desejo de submissão, quando a Lei, em cada sistema, institui sua ciência, um saber legítimo que visa assegurar a comunicação da censura aos sujeitos; isso pode ser visto nos comentários jurídicos, na ciência do Poder, nas técnicas de fazer-crer das instituições, que dá vida a estas. "O texto canônico (canônico aqui em sentido estrito, por alusão às normas jurídicas da Igreja) contém todos os expedientes necessários para sustentar uma ampla diversificação dos símbolos originários (doravante mais ou menos relacionados à divindade de Cristo, ele próprio bastante apagado pela imponente organização), contanto que os novos símbolos substitutivos assumam a relação com alguém ou alguma coisa que os doutores legítimos, mestres da propaganda da Fé, possam garantir com verossimilhança: eis o lugar-tenentevol.08, n. 03, Rio de Janeiro, 2015. pp. 1602-1628 1625
} 
Os compromissos se fazem necessários como o conjunto de relações normativas para um sujeito que procura conduzir suas próprias ações, ou que acredita que está a conduzir suas próprias ações. Não obstante, para que o sujeito constitucional possa ser engajado, possa prometer tal relação não pode ser nem uma necrologia, um obituário, uma classificação dos mortos, nem uma frugal vontade do presente. Aquele que cumpre uma promessa, como a tradição contratualista já observou, vive o compromisso, toma ele como anteriormente estabelecido e confere sua forma, até o seu desdobramento, seu desenlace, até a vida fora do compromisso (RUBENFELD, 2001.p. 128).

A trajetória temporal da autodeterminação é estendida, deixa seu rastro, se arrasta entre o passado e o futuro. A autodeterminação de Ulisses apenas é possível como uma ficção, manejada por alguém que sabe todas as consequências futuras. Alguém que pudesse agir com tal racionalidade estratégica antecipatória em qualquer ramo dos saberes seria uma (infeliz) divindade encarnada. Como aquilo que se faz presente não é muito além do que um fragmento da possibilidade da compreensão de si, o autogoverno é também um fragmento do sujeito, que precisa justificar e dar sentido para suas condutas.

O sujeito constitucional é, ao mesmo tempo, soberano e súdito. Isto só pode ser experimentado por alguém que vive os compromissos, que se engaja, que cumpre promessas. É neste contexto que a liberdade pode ser experimentada, na continuidade da atualização, no refazer, na reprodução e na representação. Na interação entre vivos e compromissos, na reescritura dos compromissos, “(...) a liberdade nunca é. Ela também apenas pode ser naquilo que está sendo." ${ }^{42}$

\title{
DEMOCRACY AND COMPROMISES: REFLEXIONS ON CONSTITUTIONALISM AND DISAGREEMENTS
}

\begin{abstract}
The article deals with the question about commitments and their relationship with democratic forms of social organization. It aims to analyze different perspectives on the tension between constitutionalism and democracy, especially the critiques to the notions of pre-commitment, to which it seeks to provide an alternative to the dichotomy that would be to put the tension on an extended temporal dimension. The methodology used for the production of the article was based on the investigation of doctrinal documents, precedents and laws. Such elements served to support the points made on the subject investigates. In conclusion it is presented the suggestion to comprehend the commitments as reasons for political action.
\end{abstract}

Keywords: Self-government; Compromises; Disagreement; Democracy; Constitutionalism.

do-Pai. (...) a Igreja ocidental modelou os dogmatismos e transporta ainda, por sob nossos olhos, seu museu vivo, um reservatório de mitos fundamentais (sobre a hierarquia, sobre o chefe, sobre a classificação social) (...)” (LEGENDRE, 1983. p. 25-26).

42 "( . . . ) Freedom never is. It too can only be in being." (RUBENFELD, 2001.p. 143). Tradução livre. vol.08, nº. 03, Rio de Janeiro, 2015.pp. 1602-1628 


\section{BIBLIOGRAFIA}

ADORNO, T. W. Negative Dialectics. London: Routledge, 1973.

ALEGRE, M. ¿Quién le teme a la igualdad?. In: ALEGRE, M.; GARGARELLA, R. (Coord.). El derecho a la igualdad: Aportes para un constitucionalismo igualitario. Buenos Aires: Lexis Nexis, 2007.

ARENDT, H. On Revolution. New York: Penguin Books, 1963.

BARRY, B. Teorías de la Justicia. Barcelona: Gedisa, 2001.

BENHABIB, S. Democratic Iterations: the local, the national, and the global. In: BENHABIB, S. Another Cosmopolitanism. Oxford: Oxford University Press, 2006.

CLÈVE, C. M. Temas de Direito Constitucional. 2. ed. Belo Horizonte: Fórum, 2013.

DERRIDA, J. Negotiations: interventions and interviews, 1971-2001. Stanford: Stanford University Press, 2002.

DWORKIN, R. Virtude Soberana. São Paulo: Martins Fontes, 2005.

ELSTER, J. Constitutional Bootstrapping in Philadelphia and Paris. In: ROSENFELD, M. (ed.) Constitutionalism, Identity, Difference, and Legitimacy: theoretical perspectives. Durham and London: Duke University Press, 1994.

Legislatures as Constituent Assemblies. In: BAUMAN, R.; KAHANA, T. The least examined branch: the role of legislatures in the constitutional state. Cambridge: Cambridge University Press, 2006.

Reason and Rationality. Princeton: Princeton University Press, 2009. 1993.

Ulysses and the Sirens: Studies in rationality and irrationality. Cambridge: Cambridge University Press,

Ulysses Unbound: Studies in Rationality, Precommitment, and Constraints. Cambridge: Cambridge University Press, 2000.

FORST, R. Contextos da justiça: filosofia política para além de liberalismo e comunitarismo. São Paulo: Boitempo, 2010.

FREUD, S. Civilization and its Discontents. New York: W. W. Norton \& Company, 1962.

GARGARELLA, R. As teorias da justiça depois de Rawls: um breve manual de filosofia política. São Paulo: Martins Fontes, 2008.

Constitucionalismo versus Democracia. In: GARGARELLA, R. Teoría y Crítica del Derecho Constitucional. Buenos Aires: Abeledo-Perrot, 2008. (b)

Theories of Democracy, the Judiciary and Social Rights. In: GARGARELLA, R. Courts and Social Transformation in New Democracies: An Institutional Voice for the Poor? Hampshire: Ashgate, 2006.

HOLMES, S. Passions and constraint: on the theory of liberal democracy. Chicago: University of Chicago Press, 1995.

JEFFERSON, T. Escritos Políticos. In: Pensadores: São Paulo: Abril Cultural, 1973. 
KELSEN, H. Teoria Geral do Direito e do Estado. São Paulo: Martins Fontes, 2000.

LEGENDRE, P. O Amor do Censor. Rio de Janeiro: Forense Universitária, 1983.

RAWLS, J. Uma teoria da justiça. São Paulo: Martins Fontes, 2000.

ROSENFELD, M. The identity of the constitutional subject: selfhood, citizenship, culture, and community. London; New York: Routledge, 2010.

RUBENFELD, J. Freedom and Time: a theory of constitutional self-government. New Haven: Yale University Press, 2001.

OfConstitutional Self-Government. In: Fordham Law Review. v. 71, 2003.

WALDRON, J. Banking Constitutional Rights: who controls withdrawals? In: Arkansas Law Review. v. 52, 1999.

Principles of Legislation. In: BAUMAN, R; KAHANA, T. The least examined branch: the role of legislatures in the constitutional state. Cambridge: Cambridge University Press, 2006.p. 17

Law and Disagreement. Oxford: Oxford University Press, 1999. (b)

Trabalho enviado em 28 de junho de 2015

Aceito em 07 de agosto de 2015. 